\title{
DIGITAL DESIGN AND TECHNOLOGY AND MARKET OUTREACH IN RURAL ZIMBABWE
}

\author{
Patience Moyo \\ Department of Graphic Design \\ patiencezmoyo@gmail.com \\ Robertson K. Tengeh \\ Department of Public Administration \& Governance ${ }^{l}$ \\ tengehr@cput.ac.za \\ ${ }^{1}$ Cape Peninsula University of Technology \\ Cape Town, South Africa, 7535
}

\begin{abstract}
Despite producing top of the range products and services, entrepreneurs in Zimbabwe's rural Gokwe face limited access to markets. Access to local and regional trading markets is further aggravated by inadequate technological infrastructure and financial resources to carry out business activities. Aim: This article investigates the role of digital design and technology in expanding market outreach in Zimbabwe. Methods: A mixed methods research design was adopted. The qualitative data, obtained from semi-structured interviews and a focus group discussion, was analysed through thematic analysis. The quantitative data was obtained from the administration of a questionnaire and used to corroborate the findings of the qualitative tool. Results: The findings revealed that while digital design and technology had little effect on identifying entrepreneurial opportunities and communicating with potential customers in Gokwe, there were clear signs that plans were being made to integrate digital technology and internet connectivity in at least one sector of the rural economy of the district. Implications: The findings may provide vital information for rural entrepreneurs and policymakers looking to benefit from the digital revolution. Recommendation: The paper encourages the use of digital marketing and advertising to take advantage of entrepreneurial opportunities.
\end{abstract}

Keywords: Digital and Design entrepreneurship, Rural entrepreneurship, Market outreach, digital media, Digital marketing, Rural Zimbabwe.

DOI: $10.21303 / 2504-5571.2021 .001758$

\section{Introduction}

Because of the growth of digital design and technology, entrepreneurs have developed a larger market share both domestically and internationally. To this end, digital design has provided significant employment opportunities [1]. In addition, digital design and technology empower companies in urban areas, making it possible to do business online.

Digital design and technology in developed and developing countries have helped increase rural prosperity [2-4]. However, despite these successes, digital design and technology need to go much further in developing countries, such as Zimbabwe's rural Gokwe [5]. Despite producing top-notch products and services, entrepreneurs in Zimbabwe's rural Gokwe face limited access to markets. Access to local and regional trading markets is further aggravated by inadequate technological infrastructure and lack of financial resources. This leads to many rural businesses shutting down or relocating to better locations like South Africa and Botswana. This highlights the critical importance of exploring the function of digital design and technology in extending business outreach in rural Zimbabwe.

\section{1. Digital Marketing and E-commerce}

Digital technology entails various information and technologies, such as the latest digital media, utilised by entrepreneurs in different sectors for business development [6]. Technological developments have led to the employment of professionals, such as graphic designers to assist in designing new products or service for specific markets [6].

Digital technology enabled people to express themselves on social media on various platforms, including Instagram and YouTube. These platforms have allowed business people, profes- 
sionals and amateurs to upload content that market their businesses [6]. Digital entrepreneurship is characterised with the pursuit of new venture opportunities, presented using the latest media and internet technologies available with the aim of attracting worldwide attention [7, 8]. Digital design plays a significant role in content creation of marketing and advertising for digital entrepreneurship; this is shown on how creativity is invaluable in this context. Creativity has a considerable advantage of stimulating entrepreneurial behaviour, innovativeness, proactiveness and risk-taking [9].

To Stone [10], the digital platform facilitates speed, agility, and innovation within an organisation. It allows the business to access information from the customer's preferences, thus the entrepreneur obtains feedback [10]. The information obtained will help the entrepreneur to improve their products and services Stone [10].

E-commerce involves purchasing and selling goods and selling on the internet [11]. It is considered a means of innovation to boost entrepreneurial activities in developing and developed countries [12, 13]. As Hua et al., [14] explain, e-commerce involves I.T procedures that support, accomplishes customer/client experience from the features of communication, design, delivery, fulfilment and assessment. Hence, E-commerce gives rural entrepreneurs the ability to reach customers beyond their localities [15]. Moreover, it has the benefit of allowing the entrepreneur to sell directly to the customer, collect data about their client's consuming patterns and provide information about product specification and product certification [15].

Pato and Teixeira [16] describe rural areas as spaces, presenting numerous activities and landscapes that encompass natural countryside, farms, villages, small towns, regional centres and industrialised rural regions, and it has a variety of endeavours, such as farming, commerce, services and small to medium enterprises.

\section{2. Digital design and technology and rural entrepreneurship}

The field of graphic design has evolved from for traditional print media to create online campaigns, animated logos, and digital artworks, all of which can be accessed by the public through digital media devices [17]. A critical aspect of designing to transmit information for rural entrepreneurship development is digital information's ability to allow the data of which it is composed to be creatively reused for social benefit in applications, such as those used for making electronic commercial transactions [18]. Punchoojit and Hongwarittorrn [19] expand upon this point by explaining that digital information provides users with instant gratification. The truth of this observation is ably borne out by users' ability to obtain instant access to any information they may desire at any time, at the lowest possible cost. Accordingly, the significance of digital design and technology for fostering rural entrepreneurship cannot be overstated. It plays a crucial role in content creation and the development of new digital systems to facilitate digital marketing.

\section{2. 1. Digital marketing and consumer satisfaction}

According to Kotler and Armstrong [20], digital marketing can be defined as a system for publicising any business's products or services through electronic media, such as the internet, social media, electronic billboards, and mobile phones. Digital marketing provides information concerning particular products or services to target audiences that are likely to purchase the products or use the services. As Ngoasong [7] explains, digital marketing allows businesses to upload promotional videos online to attract potential customers to particular digital platforms.

Rural entrepreneurship cannot be effectively promoted through digital marketing without adequate attention being accorded to customer satisfaction. Dagger, et al., [21] emphasise that customer satisfaction entails providing goods and services whose worth is perceived by customers to be sufficiently great that they feel motivated to continue to patronize the business [22].

Digital marketing can influence customer satisfaction through the effective use of the internet, enabling customers to communicate with suppliers of products and services and make suggestions concerning how particular products or services could be improved. Digital design impacts customer satisfaction by developing content related to the services offered by rural entrepreneurs [23]. In contrast, digital advertising is vital to digital marketing success, which in turn fosters rural entrepreneurship growth through the expansion of available markets. 


\section{2. 2. Digital advertising and entrepreneurial opportunities}

Digital advertising is widely acknowledged as the mainspring for advances in mobile and internet technology [24]. The same authors argue that digital marketing has replaced conventional marketing as it enabled companies to reach many more people using the internet. The digital advertisement consists of activities and information that helps to create awareness about a product or service. Publishers provide the platform for advertisers who pay for using the space [24].

How information is laid out and presented to customers on online platforms significantly influences their impressions of websites and can be a decisive factor in subsequent shopping online on particular websites. Ghaffari and Ashkiki [25] maintain that the extent to which websites are user-friendly is a significant determinant of customer satisfaction, particularly among new users. If a business organization's website is appealing and user-friendly, the functionality of its interface design would typically appeal to prospective customers. As a result, the design elements that ensure the promotion and advertisement of goods and services and the exchange of sensitive information are critical facilitators of effective online entrepreneurship [26].

As digital design is responsible for creating and generating online content for customers, the image, which a website projects, is a significant determinant of online relationships and represents the principal means of influencing customer satisfaction, perceptions of brands, and customer loyalty [27]. While visual design to a large extent determines the image which a website projects and strongly influences the decisions of customers to make initial purchases or return to make subsequent purchases, the appearance of the designs of homepages exerts an equally significant influence in determining the preferences of users to visit particular websites [28]. Other significant determinants of customer satisfaction are the arrangement of products, the layout of websites, and their overall designs. How elements, such as advertising content, text, and graphics, are combined and presented on websites also influence customers' perceptions and, ultimately, their choice whether to make a purchase or not. Consequently, it is possible to conclude that potential customers' perceptions of the images that websites project significantly influence their satisfaction with their online purchases and decisions.

From this discussion, the principal function of digital design and technology is to provide as much detail as possible on websites by making relevant content available. Kabango and Asa [29] and Rasli et al. [22] concur that the availability of detailed relevant content served as the primary motivation for customers to shop online. Furthermore, the quality of information, combined with a website's capacity to render seamless searches for products and prices, enhances satisfaction and motivates users to make further transactions or revisit a particular website [22, 29]. The innovative advertising and marketing practices that digital design and technology have made possible have significantly influenced customers' purchasing behaviour and, in turn, resulted in a proliferation of entrepreneurial opportunities in the e-commerce industry. Entrepreneurial opportunities are typically circumstances that allow the provision and exploitation of innovative services, goods, markets, raw materials, and organising procedures by creating correspondingly innovative ends, means, or meansends relationships [30, 31]. Entrepreneurial opportunities, as described by Casson [30], are opportunities to exploit innovative raw materials, goods, services, and organising structures that allow in a manner that enable outputs to be purchased at prices that exceed production costs. In this scenario, opportunities emerge as a result of some groups of people gaining access to knowledge about emerging technologies, allowing them to participate in creative business practices.

\section{3. Digital design and technology and rural entrepreneurship development in selected countries}

\section{3. 1.. Promotion of rural entrepreneurship in Africa: Botswana}

In Botswana, digital design and technology have enabled entrepreneurs to get other business opportunities and expand their markets through digital platforms. Whatsapp, facebook and twitter are extensions of e-commerce as they allow customers to interact and conduct a business transaction [2, 3]. A Small to Medium Enterprise, pseudo-named myBot, was established in 1970, based in the rural areas, and it specialises in handicrafts. 
MyBot empowers women by teaching them how to upload images on the website for marketing and advertising purposes. Their online store shows the arts and crafts with prices per product, it is customised in a way a person can view and go on to buy. Unfortunately, the website cannot process any online payments hence customers make their payment through Electronic Fund Transfer at the bank. As a result, the entrepreneur's sales turnover increased by over eighty percent, which led to myBot being the largest exporter of handicrafts [32]. Due to the business growth, myBot diversified their business into the hospitality sector; they own a restaurant, specialising in serving traditional foods. They target tourists and people that would have visited their crafts shop. The website has managed to generate profits between ten to thirty percent since it was developed.

MyBot has been using social media handle, such as facebook to market their product, consequently, they got new entrepreneurial opportunities from overseas in countries, such as Japan, U.K and other European countries [32]. Most of their online customers were repurchasing because they would have visited the crafts centre in Botswana previous; codes of the products that they would have viewed from the website were used as reference through communicating using email, and the transaction will be completed once the payment has been made [32].

\section{3. 2. Promotion of rural entrepreneurship in Asia: China}

In 2015 China embarked on an initiative called Bank of China Philanthropy (BOCP) that was later changed to China Philanthropy. It is used to market rural based products like apples, walnuts, millet, and mung beans for the four northern counties. The utilisation of an app has enabled market expansion because it brought products to the market [4]. In 2017 a team of one hundred and fifty was put together, comprising people of different professions, for instance, product design, data analysis, research and blockchain technology. This team was responsible for the content, maintenance and data that go on the app. By August 2018, the app had over 2.3 million registered users, and it had made a sale of over 134 million Yuan, approximately 5,700 types of agricultural products were sourced from 98 impoverished counties in 21 provinces, and these products were sold to over 900,000 people [4].

\section{The case of Xiaying village in central China}

The village of Xiaying started the adoption of e-commerce in 2008. Students helped local entrepreneurs adopt e-commerce slowly. There was a significant increase in the number of rural entrepreneurs who used online shops. Internet enabled the smooth flow of online transactions and offline shipping in Xiaying village. They provide instant and continuous feedback between sellers and buyers. Trade between provinces was strengthened by increasing capital flows. Xiaying village business owners use digital technology and design to promote their business. The entrepreneurs invited professionals to train them in photography, image processing, and website design, so that grabbing customers' attention with unique users interface design and absorbing special offers is easy. Consequently, their service industry has been booming in catering for particular needs and demands of customers.

Also in China, Tangjiajia is a rural area in Tangshan, a district in the east wing of Jiangning District, of Nanjing. It has been a hot spring tourist attraction because of the widespread dispersal of geothermal groundwater beside Nanjing-Zhenjiang Ridge, Tangshan. In 2013, the utilisation of digital design and technology for market outreach was depicted when the government stepped in to advertise the Tangjiajia grassroots hot springs. As a result, billboards were erected, websites were developed, and snapshots were taken, highlighting Tangjiajia, the content was uploaded on WeChat and was accessed by the public [33].

\section{3. 3. Promotion of rural entrepreneurship in Turkey rural women entrepreneurship}

The success of rural businesses in Turkey is based on media literacy and women empowerment through operating businesses using social media platforms. Kawamorita et al., [34] define media literacy as "...the ability to access information effectively, analyses, evaluate and create media in a variety of forms". Rural women entrepreneurs in Soma started their businesses with technology, implemented through media literacy and entrepreneurial skill. Soma women's workshop cooperative empowered women from full-time housewives to successful businesswomen; this 
was executed through training and opportunities to generate income. Business activities in the area are handcrafts, towel design, sewing and embroidery, implementation of digital technologies, selling their products on websites, increased visibility and market outreach through digital design. In addition, the use of social media for marketing and advertising purposes, for instance, WhatsApp, YouTube, and Instagram and television appearance [34].

\section{3. 4. Promotion of entrepreneurship in Europe: Italy urban context}

Digital design and technology have influenced entrepreneurial opportunities and market outreach by facilitating an entirely virtual restaurant in urban Italy. A city restaurant was used for comparison purposes because this paper focused on rural-based entrepreneurs. Bistrot is a Northern Italian cuisine restaurant that serves recipes developed by the chef's family in Northern Italy. The restaurant uses handheld devices to take orders from customers, and the information is transmitted to the kitchen, resulting in improved customer service and greater efficiency and effectiveness. Digital design plays a significant role in Bistrot because it has a website that provides their location, menus, and descriptions of their Italian dishes in English and Italian.

Additionally, Bistrot's app was designed to enable customers to make reservations, show the seating arrangement, number of seats, and sends a text message to staff when the customer makes a reservation. The app has allowed Bistrot to expand its customer base by reaching tourists and local people alike. Tourists check Bristrot's reviews on websites like Trip Advisor, resulting in new business opportunities [35].

This article aimed to ascertain the role that digital design and technology played in facilitating rural entrepreneurship development. To this end, the researchers examined the effect of digital design and technology on the rural entrepreneur's ability to identify entrepreneurial opportunities and expand their markets.

\section{Materials and Methods}

The researcher elected to use qualitative and quantitative research methods by developing a mixed-methods research design [36]. Doing so enables researchers to obtain insights from collecting and analysing both qualitative and quantitative data and making use of a range of different inference techniques, to increase the breadth and depth of the understanding, which emerges of the phenomenon, which is being studied and also to generate two mutually corroborating sets of data [37]. Among the other benefits of mixed methods, research is complementarity, which emerges from using one method to explain and expand upon by the other method's findings.

Since little relevant literature was available, the researchers adopted the case study method since it permits them to interpret, analyze, and evaluate data within specific contexts. A case study investigates a contemporary real-life phenomenon through a comprehensive contextual evaluation of a small number of conditions and events and their relationships [38]. The researcher considered a case study to be appropriate owing to the exploratory nature of the study.

\section{1. Techniques and procedures}

Sampling is a time-honoured technique for identifying and collecting data from a specific group of people who embody the broader populations, from which they are drawn following the researcher's interests. As Kumar [39] states, it is almost always difficult to collect data from all members of a population with characteristics relevant to a research inquiry. The non-probability sampling technique is often preferred in selecting participants when the researcher does not know the exact number and location of population components. Purposive sampling was chosen for this study in order to collect data that were important to the study, as the researcher recognized that data obtained from participants who lacked adequate information about the research subject could jeopardize the analysis.

As a result, researchers often use their judgment or credible informants to select participants through judgmental sampling who they believe will provide the information they need [39]. Hence, the participants and respondents were purposefully chosen following the study's objectives. The business activities of the participants and respondents included farming, manufacturing, and crafts. 


\section{2. Data collection and research instruments}

The qualitative study was conducted through interviews and a focus group discussion and was advised by the literature. The researcher augmented the data they yielded with direct observations of the participants, appropriate visual material, and document analysis. The quantitative data was obtained through the administration of a questionnaire.

To gather rich data for the qualitative analysis, the researchers conducted one-on-one interviews and facilitated a focus group discussion to gain an understanding of urban and rural entrepreneurs' attitudes, values, and opinions about digital design and e-commerce.

The quantitative data, which the administration of the questionnaire generated, was used to validate the findings, which emerged from the interviews and the focus group discussion by means of concurrent triangulation, through the simultaneous collection of the quantitative and qualitative data and by assessing the two sets of data to determine whether they merged or were either dissimilar or sequential [40]. This process occurs during data analysis, and the ability to make precise comparisons between sets of quantitative numerical and detailed qualitative verbal data is unique to mixed methods studies. In addition, concurrent triangulation helps this study because it allows independent verification of results and decreases the time needed for data collection [40].

The criteria for participating in the study, by completing a questionnaire or participating in the focus group discussion or the interviews, required prospective participants to be entrepreneurs who operated small to medium-sized enterprises, which had been in existence for five years or more, and be based in either Gokwe or the urban district of Harare. The interviews had durations of between forty-five minutes to an hour and a half. Furthermore, the researcher prioritised the participants' education level because the adoption of technology in business requires essential reading and writing skills.

\section{Results}

\section{1. Qualitative results}

\section{1. 1. Digital design and technology and entrepreneurial opportunities}

The results, presented in this theme are based on the research question on how digital design and technology influence identifying entrepreneurial opportunities and communication with potential markets. Specifically, the entrepreneurs were asked how their markets extend, if they had customers outside Zimbabwe markets and whether they like to reach it. New entrepreneurial opportunities that they able to identify and entrepreneurial opportunities, available to them at present. Methods they use to market their products or services, problems in reaching their target market. The business people were asked if they were aware of any essential differences between the entrepreneurial opportunities available to their businesses, and those, available to businesses, located in the city. They were asked if they have any information concerning the customers of their competitor. Finally, the entrepreneurs were questioned on their relationship with the community and whether they participated in any cooperative activities to benefit the community.

The interviews, carried out with the key entrepreneurs, show that the market outreach for most entrepreneurs in Gokwe is mainly their surrounding areas within the country's Midlands region. These areas include towns like Gweru and Kwekwe as well as Kadoma, respectively. The findings show that the majority of businesspeople target only rural and suburban customers with their marketing efforts. However, the researcher found out that some entrepreneurs have customers who buy from them in bulk for resale purposes, which indicates that their produce in rural areas is also of high standards and can meet international markets standards in rural China and elsewhere neighbouring countries. On the role of market expansion for their businesses, most entrepreneurs had this to say:

"...we do not have a market outside Zimbabwe yah. But we do supply the likes of Choppies shop you know the supermarket then food world those are the two major customers we have then the community as a whole."(Entrepreneur 4-Farmer).

"My market is the auction floor that is TIMB; it is the middlemen.... l have no interaction with the client whatsoever... I think the Asian market; l would want to try to sell in our neighbouring countries like Botswana, South Africa, Angola" (Entrepreneur 5-Farmer).

Although most entrepreneurs struggle to expand their businesses to local towns and cities as well as other urban areas in the country, results show that one entrepreneur from Gokwe even has 
customers and clients outside of the country. The possibility of expanding to other countries is dependent on the type of product he sells. This entrepreneur sells and distributes Paprika to the local markets and exports the product to outside countries. To explain why he has been able to expand his business to outside countries; he had this to say about his business model:

"Yes, we have customers outside Zimbabwe in South Africa; in South Africa we supply paprika, so we supply paprika in Zimbabwe and South Africa due to the fact that our paprika has no chemical residue yah."(Entrepreneur 3-Farmer).

As indicated in the findings above, including other key excerpts, most entrepreneurs struggle to better market outreach because they used old or primitive advertising techniques, making it difficult for them to reach their desired target audience. Most entrepreneurs heavily rely on referrals and below-the-line advertising techniques that can only reach a very small to a minimum number of clients, which are problematic to their businesses' growth. To get a better insight on this point of view, this is what some entrepreneurs had to say:

"I have managed to also market my business utilising word of mouth, flyers, business cards, brochures, posters and catalogues." (Entrepreneur 7-Carpenter).

"......we only market through referrals were so and so tells so and so that if you go there you will find $A, B, C \ldots$ In our business besides TIMB the regulating board, we also have Tobacco Sale Floor and Boka those are the tobacco auction companies."(Entrepreneur 5-Farmer).

This is not the story for business owners, based in the city utilising digital marketing to advertise and market their business based on their market outreach. Businesspeople who operate in urban areas have more extensive market outreach compared to their rural counterparts.

"So far, it has just been mainly Harare and a few in Masvingo, Bulawayo a bit of engagement in Mutare that's it."(Entrepreneur 1-Motivational Speaker).

"Yes we do actually, there is the Mozambican government and also the Frelimo party from Mozambique... in Zimbabwe l have clients here in the city, l have walk-ins, companies and sometimes schools and colleges."(Entrepreneur 6-Advertising).

Entrepreneurs in Gokwe have different entrepreneurial opportunities compared to their urban counterparts. These differences are spelt out from the differing return on investment opportunities where resources are being channelled based on thriving entrepreneurial activity by the government and other economic investments based on available technology. From rural entrepreneurs' point of view, especially from those entrepreneurs in Gokwe, their biggest challenge to reaching their desired markets is worsened by the fact that they live far from the markets and decision-makers because most company head offices where they could get access to funding and market information are located in the city. This causes delays in access to useful information that could change their business. Other challenges include high transport costs whenever they want to transport their produce to the markets outside of their market outreach, increasing their production costs.

"...entrepreneurs that are in town the urban areas they have got wider network area they are networking with a lot of people, a lot of suppliers, a lot of buyers more than us who are in the rural area because we are not visible on were we should be visible...."(Entrepreneur 3-Farmer).

"Those closer to TIMB and auction companies do not incur transport costs...the farmers that make sales of their product first because they have access to any information from the auction floor quicker than us."(Entrepreneur 5-Farmer).

So far, the current findings, projected in the theme, support the notion that digital design and technology impacts the identification of entrepreneurial opportunities and expansion. The results 
point to the fact that entrepreneurs in Gokwe are now getting used to digital marketing through the widespread use of digital technology and cyberspace. Gokwe rural entrepreneurs' views and opinions also show that they want to explore other digital design interventions to boost their businesses. The following opportunities are available to entrepreneurs:

"When we supply tomatoes to the market some of the tomatoes, l think eighty percent of the tomatoes are bought, but twenty percent rot and they are thrown away, but then the opportunity now is to develop a plant for tomato puree."(Entrepreneur 3-Farmer)

Nonetheless, the entrepreneurial opportunities, which are available to urban business, are generally fundamentally different from those, which are available to rural entrepreneurs, in that they have the potential to enable them to diversify their business activities into other sectors and even to penetrate global markets, as is evident from the following two excerpts:

“... creating a stable ground using expanded polystyrene that type of expanded polystyrene called geoform so this one is an untapped market especially here in Africa... construction of walls we have what we call soundproof walls all those things are done using styrofoam."(Entrepreneur 8-Manufacturer of polyether-derived foams).

“... there is an untapped market for printing Afrocentric designs on t-shirts in our country... creating these Afrocentric designs and selling to countries such as the UK, America and France... I want to attract the Chinese market as well."(Entrepreneur 6-Advertising).

\section{1. 2. Digital design in expanding marketing}

Open-ended interviews demonstrate that most entrepreneurs create their marketing material themselves, while some hire professionals to develop their content. Most of the entrepreneurs identified the need to involve professionals to implement digital marketing fully. It was also noted, that while entrepreneurs use various marketing techniques to market their business, they encounter some problems, as pointed out in the following word verbatim accounts:

"...we follow up these public gatherings and make sure that at every farming gathering that is there, someone is there, someone has to give a phone number, someone has to a flyer, someone has to give make us known..."(Entrepreneur 8-Farmer).

"...we use digital marketing which is basically Facebook the fact that with Facebook you do not need a domain...” (Entrepreneur 3-Farmer).

“... a problem with reaching out to your target market talk about communication; talk about perception just simple perception will really be a problem when you are trying to reach out to your market.'(Entrepreneur 9-Farmer).

\section{2. Findings from the questionnaire}

An overwhelming majority (78 \%) of respondents believed that digital design and technology influences the identification of entrepreneurial opportunities and market outreach (very important), and $22 \%$ said it is (extremely important).

\section{3. Discussion of the findings}

The findings on how digital design and technology impacts entrepreneurial opportunities and communication with potential markets are covered in this section.

\section{3. 1. The size of present-day markets of entrepreneurs in Gokwe}

The interview results revealed that the entrepreneurs in Gokwe have limiting markets, as most of them do not have customers outside Zimbabwe. These results confirm Trendov's [41] suggestion that technology could expose SMEs to global markets. 
There is an entrepreneur (Entrepreneur 5-Farmer) who is into tobacco farming. He only sells to the auction floor TIMB that is the only client he has because the tobacco market is monopolised, there are no other auction floors in the country except for TIMB, which leaves a considerable gap to be field concerning acquiring other buyers outside the country. By contract (Entrepreneur 3-Farmer) revealed that he had a loyal customer in South Africa that buys paprika from him for many years, the paprika is not processed, it is organic, this highlights the standard of the quality that he produces.

\section{3. 2. Exposure for cooperatives through assistance from the government}

In the focus group interview, the participants demonstrated that belonging to a cooperative grants them the opportunity to sell their products locally and overseers and benefit from the government. The rest of the entrepreneurs do not have customers outside Zimbabwe.

\section{3. 3. The potential benefits of digital electronic devices for entrepreneurs}

According to the findings, most respondents have smartphones with social media applications, installed on them, but they hardly utilise them. Urban-based entrepreneurs use some applications, such as Facebook, Instagram, and Twitter, for business purposes. Unquestionably, social media has changed the landscape of business in the city and their market as well. Most of the business people (44\%) confirmed having ownai, and the other (56\%) did not have either ownai or tengah (the local marketing websites that are available for use). However, urban-based business people are familiar with them. Only $22 \%$ utilised ownai, and an overwhelming $78 \%$ has not utilised either of the two websites. Furthermore, an overwhelming $56 \%$ have not conducted business on any international e-commerce websites, only $11 \%$ on Alibaba and $33 \%$ on Amazon. These results depicted that there is room for improvement in terms of buying and selling online in Gokwe.

Furthermore, digital design and technology influences the identification of entrepreneurial opportunities and communication with potential markets. For instance, $78 \%$ of entrepreneurs indicated that it is very important, and $22 \%$ said it is extremely important for their entrepreneurial activities, the importance of possessing the necessary electronic gadgets for digital marketing, conducting business online and technology-driven marketing being a problem in doing business.

\section{3. 4. Entrepreneurial opportunities}

During the interviews, it was mentioned, that entrepreneurs want to pursue business opportunities, but they do not have the appropriate technologies to actualise them. Previous research has shown that enabling technologies have been a critical advantage to businesses over the past decade [42]. Thus, the awareness that the opportunities, available to them, are inadequate, and the desire to seek new possibilities is crucial for future adoption. Accordingly, Entrepreneur 5 (who is a tobacco farmer) is interested in exploring the potential of tobacco processing due to its scarcity of players. This is against the status quo, which dictates that processing firms set selling rates and tobacco farmers are obliged to accept whatever they are offered, excellent or poor. Two additional farmers (Entrepreneurs 3 and 4) addressed the business opportunity of producing tomato puree instead of letting the tomatoes rot.

The focus group discussions' results suggested an opportunity in interior design that business people want to explore with the appropriate interventions. They also noted that entrepreneurial prospects vary by sector and geography. For example, all entrepreneurs interviewed conceded that rural areas offer fewer entrepreneurial opportunities than urban areas. Despite this, urban entrepreneurs, like entrepreneurs in rural areas, want to expand their markets and seek new opportunities. Expansion of the market necessitates the intensive use of digital design and technology and the exploration of new opportunities.

\section{Limitation and scope for future studies}

As the study focused on the role that digital design and technology can play in the growth of entrepreneurship, in Gokwe, the researcher placed a great deal of emphasis on information, marketing, advertising, and technology, as they are widely acknowledged to be among the main drivers of entrepreneurship. A more comprehensive research may have involved an examination of 
the effect of other drivers. Case studies have intrinsic drawbacks, one of which is the improbability of generalising their observations to comparable environments. Another concern is the unquantifiable subjectivity of individual qualitative researchers, whose influence the researchers, attempted to mitigate by using mixed methods research design and triangulation.

\section{Conclusions}

While the internet and digital technology have made considerable strides in recent years, the expected developments in rural Africa have not been realized as of late. Therefore, the main goal of this article was to advance the case for the development of rural entrepreneurship through e-commerce. As such, the core premise of this paper was twofold. First, to ascertain the role that digital design and technology played in facilitating rural entrepreneurship development. Second, finally, to consider the effect of digital design and technology on rural entrepreneurs' ability to identify entrepreneurial opportunities and expand their markets.

The participants were asked how they made and received payments in their business transactions, which methods they used to communicate with customers, and how they disseminated information concerning their products or services. It was found, that most relied on money transfers through either EcoCash or ZIPIT or cash transactions, owing to their inability to make or receive payments online. Although most of them communicated with customers by making calls, some communicated with suppliers through e-mail messages. All of the rural entrepreneurs used traditional methods to advertise their products or services, while several of the urban entrepreneurs maintained that they could not justify the expense of having websites, professionally designed and developed, if they were unable to make business transactions online. Accordingly, it could be concluded, that digital design and technology played no role in developing entrepreneurship among rural entrepreneurs and a severely limited role among urban entrepreneurs. As nearly all of the participants expressed the desire to integrate digital technology into their business practices and emphasised the role of entrepreneurship in contributing to the GDP of the country and creating employment, it was evident that in all entrepreneurial sectors the growth was predicated on two crucial preconditions, namely, the development of net-enabled ecosystems and the ability to make and receive payments online.

In terms of market outreach, the participants were asked whether they had customers outside of Zimbabwe, whether they had been able to identify new entrepreneurial opportunities, and whether they perceived any essential differences between the available entrepreneurial opportunities in Gokwe those in urban centres. These questions were asked to understand the methods, used by the respondents to market their products or services and their perceptions of entrepreneurial opportunities in their respective areas. From the interviews, only one of the rural entrepreneurs exported his produce to a country outside of Zimbabwe, namely, South Africa. In addition, although the products of the crafters who participated in the focus group discussion were sold on their behalf from Harare, they were unable to sell their products outside of Gokwe, other than through the crafts centre. Thus, although it was envisaged, that the collective marketing of their crafts would continue online, they stood to be exposed to a far broader market than would have been conceivable previously. By contrast, the findings revealed that the markets of the rural entrepreneurs in Gokwe who participated in the study were, generally, extremely small and confined to their district, as very few had customers even in the Matabeleland region. This finding appears to be consistent with their reliance on traditional methods of marketing and advertising. Although some were aware of potential new entrepreneurial opportunities, they were equally aware that they lacked access to the technologies, which could enable them to exploit them. As it has already been noted, while the entrepreneurs also expressed the desire to expand their markets and were able to identify promising opportunities, they felt that they could not afford to create websites solely for advertising.

\section{Recommendations}

Several sources of the literature, which the researchers consulted before conducting the study, were highly relevant to the finding that limited market outreach is a major problem for Gokwe most entrepreneurs. Therefore, increasing the efficiency of entrepreneurial activities through digital design and technology is a must. At present, entrepreneurs in Zimbabwe are obliged to rely on money transfers, bank transfers, or cash to pay suppliers or receive payments from customers. 
While carrying substantial amounts of cash often entails considerable risks, mobile money transfers tend to be affected by network failures and bank transfers can be slow and unreliable, owing to inefficient systems. Although the point has been raised several times, the researcher feels compelled to emphasise the urgent need for the banking sector to take all reasonable measures to make it possible to process transactions online by increasing security against cybercrime and encouraging currency circulation.

The findings indicate that while digital design and technology have significant benefits for rural entrepreneurs, these benefits are less likely to be realized without considerable investment and concerted efforts to enact policies that promote the growth of entrepreneurial ecosystems in specific rural areas. Hence, the researchers propose that the government ascertain each rural area's particular needs and choose the most appropriate technologies for entrepreneurial operation. The government should develop and introduce effective interventions to assist rural entrepreneurs in reaping the benefits of digital marketing and advertisement. Rural and Urban entrepreneurs will be able to extend their current markets and find and assess new entrepreneurial opportunities by establishing digital marketing platforms.

\section{References}

[1] Ayandibu, A., Houghton, J. O. (2017). The role of small and medium scale enterprise in local economic development. Journal of the Academy of Business and Retail Management, 11 (2), 133-139.

[2] Bocconcelli, R., Cioppi, M. Pagano, A., (2017). Social media as a resource in SMEs' sales process. Journal of Business \& Industrial Marketing, 32 (5), 693-709. doi: http://doi.org/10.1108/jbim-11-2014-0244

[3] Jones, N., Borgman, R., Ulusoy, E. (2015). Impact of social media on small businesses. Journal of Small Business and Enterprise Development, 22 (4), 611-632. doi: http://doi.org/10.1108/jsbed-09-2013-0133

[4] Huang, C.-C., Jin, H., Zhang, J., Zheng, Q., Chen, Y., Cheung, S., Liu, C. (2020). The effects of an innovative e-commerce poverty alleviation platform on Chinese rural laborer skills development and family well-being. Children and Youth Services Review, 116, 105189. doi: http://doi.org/10.1016/j.childyouth.2020.105189

[5] Gwaka, L. T. (2017). Digital Technologies and Sustainable Livestock Systems in Rural Communities. The Electronic Journal of Information Systems in Developing Countries, 81 (1), 1-24. doi: http://doi.org/10.1002/j.1681-4835.2017.tb00598.x

[6] Hisrich, R. D., Soltanifar, M.; Soltanifar, M., Hughes, M., Göcke, L. (Eds.) (2020). Unleashing the creativity of entrepreneurs with digital technologies. Digital Entrepreneurship, Future of Business and Finance. Cham: Springer, 23-49. doi: http:// doi.org/10.1007/978-3-030-53914-6_2

[7] Ngoasong, M. Z. (2017). Digital entrepreneurship in a resource-scarce context. A focus on entrepreneurial digital competencies. Journal of Small Business and Enterprise Development, 25 (3), 483-500. doi: http://doi.org/10.1108/jsbed-01-2017-0014

[8] Davidson, E., Vaast, E. (2010). Digital Entrepreneurship and Its Sociomaterial Enactment. 2010 43rd Hawaii International Conference on System Sciences. doi: http://doi.org/10.1109/hicss.2010.150

[9] Kuratko, D. F., Morris, M. H. (2018). Corporate Entrepreneurship: A Critical Challenge for Educators and Researchers. Entrepreneurship Education and Pedagogy, 1 (1), 42-60. doi: http://doi.org/10.1177/2515127417737291

[10] Stone, S. M. (2019). Digitally Deaf. Management for Professionals. doi: http://doi.org/10.1007/978-3-030-01833-7

[11] Turban, E., Lee, J. K., King, D., McKay, J., Marshall, P. (2008). Electronic Commerce: A Managerial Perspective. Upper Saddle River: Pearson Prentice Hall.

[12] Alyoubi, A. A. (2015). E-commerce in Developing Countries and how to Develop them during the Introduction of Modern Systems. Procedia Computer Science, 65, 479-483. doi: http://doi.org/10.1016/j.procs.2015.09.127

[13] Kurnia, S., Choudrie, J., Mahbubur, R. M., Alzougool, B. (2015). E-commerce technology adoption: A Malaysian grocery SME retail sector study. Journal of Business Research, 68 (9), 1906-1918. doi: http://doi.org/10.1016/j.jbusres.2014.12.010

[14] Hua, N., Morosan, C., DeFranco, A. (2015). The other side of technology adoption: Examining the relationships between e-commerce expenses and hotel performance. International Journal of Hospitality Management, 45, 109-120. doi: http:// doi.org/10.1016/j.ijhm.2014.12.001

[15] Lee, Y.-L., Tao, K.-C. (2018). The Barriers and Key Breakthrough Factors for E-commerce Implementation for Small Agriculture Firms in Taiwan Rural Areas. Proceedings of the 2nd International Conference on E-Society, E-Education and E-Technology - ICSET 2018, 94-97. doi: http://doi.org/10.1145/3268808.3268820

[16] Pato, M. L., Teixeira, A. A. C. (2014). Twenty Years of Rural Entrepreneurship: A Bibliometric Survey. Sociologia Ruralis, 56 (1), 3-28. doi: http://doi.org/10.1111/soru.12058

[17] Abushawali, M., Lim, Y. P., Bedu, A. R. (2013). The Impact of New Digital Media on Graphic Designer in Jordan. 2013 International Conference on Informatics and Creative Multimedia, 274-277. doi: http://doi.org/10.1109/icicm.2013.34 
[18] Paskin, N. (2006). Naming and meaning: key to the management of intellectual property in digital media. The Europe-China Conference on Intellectual Property in Digital Media (IPDM06). Shanghai.

[19] Punchoojit, L., Hongwarittorrn, N. (2017). Usability Studies on Mobile User Interface Design Patterns: A Systematic Literature Review. Advances in Human-Computer Interaction, 2017, 1-22. doi: http://doi.org/10.1155/2017/6787504

[20] Kotler, P., Armstrong, G. (2012). Principles of marketing. New Jersey: Pearson Prentice Hall, 954.

[21] Bowden-Everson, J. L.-H., Dagger, T. S., Elliott, G. (2013). Engaging Customers for Loyalty in the Restaurant Industry: The Role of Satisfaction, Trust, and Delight. Journal of Foodservice Business Research, 16 (1), 52-75. doi: http://doi.org/10.1080/ 15378020.2013.761025

[22] Rasli, S., Khairi, N., Ayathuray, H., Sudirman, M. S. (2018). The impact of e-business website quality on customer satisfaction. Selangor Business Review, 3 (1), 37-45.

[23] Batani, J., Denhere, P. T., Mawere, T. (2015). The role of e-commerce in resuscitating the economy of Zimbabwe. International Journal of Management \& Business Studies, 5 (2), 44-48.

[24] Chen, G., Cox, J. H., Uluagac, A. S., Copeland, J. A. (2016). In-Depth Survey of Digital Advertising Technologies. IEEE Communications Surveys \& Tutorials, 18 (3), 2124-2148. doi: http://doi.org/10.1109/comst.2016.2519912

[25] Ghaffari, A., Ashkiki, M. F. (2015). The impact on the quality of the website to buy online customers. Journal of Applied Environmental and Biological Sciences, 5 (11S), 516-526.

[26] Reuschke, D., Mason, C. (2020). The engagement of home-based businesses in the digital economy. Futures, 102542. doi: http://doi.org/10.1016/j.futures.2020.102542

[27] Išoraitè, M. (2018). Brand image development. Ecoforum, 7 (1 (14)).

[28] Nasser, M. A.-, Islam, R., Abidin, I. S. Z., Azam, M., Prabhakar, A. C. (2015). Analysis of E-service Quality through Online Shopping. Research Journal of Business Management, 9 (3), 422-442. doi: http://doi.org/10.3923/rjbm.2015.422.442

[29] Mbayo Kabango, C., Romeo Asa, A. (2015). Factors influencing e-commerce development: Implications for the developing countries. International Journal Of Innovation And Economic Development, 1 (1), 59-66. doi: http://doi.org/10.18775/ ijied.1849-7551-7020.2015.11.2006

[30] Casson, M. C. (2003). The Entrepreneur: An Economic Theory. Cheltenham: Edward Elgar, 271.

[31] Shane, S., Venkataraman, S. (2000). The Promise of Entrepreneurship as a Field of Research. Academy of Management Review, 25 (1), 217-226. doi: http://doi.org/10.5465/amr.2000.2791611

[32] Shemi, A. P., Procter, C. (2018). E-commerce and entrepreneurship in SMEs: case of myBot. Journal of Small Business and Enterprise Development, 25 (3), 501-520. doi: http://doi.org/10.1108/jsbed-03-2017-0088

[33] Shen, M., Shen, J. (2019). State-led commodification of rural China and the sustainable provision of public goods in question: A case study of Tangjiajia, Nanjing. Journal of Rural Studies. doi: http://doi.org/10.1016/j.jrurstud.2019.03.004

[34] Kawamorita, H., Takahashi, N., Demiryurek, K. (2020). Media Literacy and Rural Women Entrepreneurship: Experience from Japan and Turkey. Nordic Journal of Media Management, 1 (3), 361-383. doi: http://doi.org/10.5278/njmm.2597-0445.5898

[35] Depaoli, P., Za, S., Scornavacca, E. (2020). A model for digital development of SMEs: an interaction-based approach. Journal of Small Business and Enterprise Development, 27 (7), 1049-1068. doi: http://doi.org/10.1108/jsbed-06-2020-0219

[36] Almalki, S. (2016). Integrating Quantitative and Qualitative Data in Mixed Methods Research - Challenges and Benefits. Journal of Education and Learning, 5 (3), 288-296. doi: http://doi.org/10.5539/jel.v5n3p288

[37] Kowalczyk, D. (2016). Research methodologies: quantitative, qualitative, and mixed methods. Available at: http://study.com/ academy/lesson/research-methodologies-quantitative-qualitative-mixed-method.html Last accessed: 17.06.2019

[38] Yin, R. K. (2018). Case study research and applications: design and methods. California: Sage Publications, Inc.

[39] Kumar, R. (2011). Research methodology a step-by-step guide for beginners. London: Sage Publications Ltd.

[40] Creswell, J. W. (2009). Research design: Qualitative, quantitative and mixed methods approaches. California: Sage Publications, Inc.

[41] Trendov, N. M., Varas, S., Zeng, M. (2018). Digital technologies in agriculture and rural areas - Status Report. Rome.

[42] Bechtel, M., Briggs, B., Buchholz, S. (2020). Deloitte Insights. Tech trends Deloitte Development LLC. 